\title{
Pengolahan Tandan Benih Kelapa Sawit (Elaeis guiinensis Jacq) di Pusat Penelitian Kelapa Sawit Marihat, Sumatera Utara
}

\section{Processing of Oil Palm (Elaeis guiinensis Jacq.) Seed Bunch in Pusat Penelitian Kelapa Sawit Marihat, North Sumatera}

\author{
Benny Julyan, Abdul Qadir*, dan Supijatno \\ Departemen Agronomi dan Hortikultura, Fakultas Pertanian, Institut Pertanian Bogor \\ (Bogor Agricultural University), Jl. Meranti, Kampus IPB Darmaga, Bogor 16680, Indonesia \\ Telp.\&Faks.62-251-8629353 e-mail agronipb@indo.net.id \\ *Penulis untuk korespondensi: abdulqadir_benih@yahoo.co.id
}

Disetujui 6 November 2017 /Published online 14 November 2017

\begin{abstract}
An internship and research activity was conducted in Pusat Penelitian Kelapa Sawit, Marihat, North Sumatera started from February until July 2011. The main purpose of this internship and research is to improve knowledge, skills, experience about seed production and to research the seed viability based on seed place of palm oil fruit bunch. The primary data obtained by two things, there is participating in four SUSBHT (Satuan Usaha Strategis - Bahan Tanaman) Divisions such as Breeding, Parent Tree, Seed Production and Quality Control. The second is a research program about tetrazolium viability and germinated seed test based on seed place in a fruit bunch. The processing of palm oil seed bunch consist of chopping, fermentation, fruit striping, peeling, breaking dormancy, and germinating. The conclusion of the research is the best part to make a good seed in a middle part of fruit bunch.
\end{abstract}

Keywords: tetrazolium viability test, germinated oil palm seed, seed place, Pusat Penelitian Kelapa Sawit

\begin{abstract}
ABSTRAK
Kegiatan penelitian dilakukan di Pusat Penelitian Kelapa Sawit, Marihat, Sumatera Utara mulai dari bulan Februari sampai Juli 2011. Tujuan utama dari penelitian ini adalah untuk meningkatkan pengetahuan, keterampilan, pengalaman tentang produksi benih dan untuk penelitian viabilitas benih berdasarkan tempat benih dalam tandan buah kelapa sawit. Data primer diperoleh dengan dua hal, berpartisipasi dalam empat Divisi SUS-BHT (Satuan Usaha Strategis - Bahan Tanaman) seperti Breeding, Pohon Induk, Produksi Benih dan Quality Control. Yang kedua adalah program penelitian tentang kelayakan tetrazolium dan uji benih berkecambah berdasarkan tempat benih dalam tandan buah. Pengolahan tandan bibit kelapa sawit terdiri dari memotong, fermentasi, membelah buah, mengupas, mematahkan dormansi, dan mengecambahkan. Kesimpulan dari penelitian ini adalah bagian terbaik untuk membuat benih yang baik adalah di bagian tengah tandan buah.
\end{abstract}

Kata kunci : perkecambahan benih kelapa sawit, posisi benih, pusat penelitian kelapa sawit, uji tetrazolium 


\section{PENDAHULUAN}

Komoditas tanaman perkebunan di Indonesia merupakan salah satu komoditas unggulan penyumbang devisa terbesar dari sektor pertanian. Kelapa sawit di Indonesia dewasa ini merupakan komoditas primadona. Luas dari perkebunan ini terus berkembang, seiring dengan banyaknya permintaan akan kebutuhan minyak nabati. Peningkatan luas lahan kelapa sawit Indonesia pada tahun 2003 sebesar $5.283 .557 \mathrm{Ha}$ meningkat menjadi 5.447.563 Ha pada tahun 2004 dengan tingkat pertumbuhan $3 \%$ bahkan akan lebih di tahun mendatang (Pahan, 2010). Kegiatan produksi ini tidak hanya didominasi oleh perkebunan besar negara maupun perkebunan swasta, saat ini perkebunan rakyat mulai memasuki babak baru dalam usaha perkebunan komoditas kelapa sawit.

Produksi benih merupakan aspek yang paling vital bagi kegiatan pertanaman. Pemilihan benih berkualitas baik menentukan hasil yang menghasilkan hubungan berbanding lurus dengan banyaknya hasil produksi kelak. Pada komoditas tanaman perkebunan, aspek pemilihan benih merupakan aspek yang harus dijaga dengan baik, dikarenakan akan mempengaruhi pertumbuhan dan hasil produksi ke depan.

Benih kelapa sawit merupakan benih yang unik dikarenakan memiliki cangkang yang paling tebal dibandingkan dengan komoditas perkebunan lainnya. Permasalahan lain yang menghinggapi perbenihan kelapa sawit yaitu masih adanya beberapa lot benih yang tidak tumbuh pada waktunya dan ketidakseragaman pertumbuhan.

Pemilihan benih yang baik terkait dengan viabilitas benih. Viabilitas awal benih dipengaruhi oleh tingkat kemasakan benih. Menurut Sadjad et al. (1980) benih mencapai kualitas maksimumnya pada saat masak fisiologis, ketika fase masak fisiologis terjadi, fase kemunduran benih turut terjadi hingga benih tersebut ditanam. Pranoto et al. (1990) menyatakan bahwa pada saat masak fisiologis endosperm monokotil biasanya sudah mencapai perkembangan yang maksimum.

Permasalahan mengenai produksi benih unggul sering dihadapkan pada beberapa aspek di dalam produksi tersebut, seperti penanganan dari tandan hingga ke prosessing kecambah. Sehingga penelitian ini bertujuan untuk memperoleh informasi mengenai manajemen dan sistem produksi kecambah kelapa sawit di Pusat Penelitian Kelapa Sawit, mengetahui penanganan dan prosessing tandan kelapa sawit hingga menjadi kecambah siap jual, dan untuk mengetahui pengaruh letak dan varietas terhadap viabilitas embrio serta daya kecambah benih kelapa sawit.

\section{METODE PENELITIAN}

Kegiatan penelitian dilaksanakan di Pusat Penelitian Kelapa Sawit yang berlokasi di Marihat Ulu, Pematang Siantar, Sumatera Utara selama empat bulan empat belas hari, mulai bulan Februari hingga Juli 2011.

Pengumpulan data dan informasi dilakukan dengan metode langsung dan tidak langsung. Data primer diperoleh melalui pengamatan di lapang, kegiatan pengujian dan wawancara dengan staf penanggung jawab. Hal yang menjadi bidang pengamatan yaitu prinsip pemuliaan tanaman, metode pengukuran kadar minyak, pertumbuhan vegetatif, karakter pohon induk betina dan pohon induk bapak, karakter bunga, proses persilangan, pengamatan karakter tandan, panen tandan benih, persiapan tandan (pencincangan, pengupasan, pengikisan dan pengeringan), pematahan dormansi (perendaman, dan pemanasan), perkecambahan (penyiraman, pengamatan kecambah dan pemilihan), dan standar pengawasan hasil kerja. Data primer lainnya yang didapat yaitu hasil kegiatan pengujian viabilitas tetrazolium embrio dan daya kecambah benih kelapa sawit berdasarkan letak berondolan dengan peubah persentase viabilitas, persentase benih non inti, persentase daya kecambah persentase potensi tumbuh maksimum, dan persentase kecambah abnormal.

Data sekunder diperoleh melalui observasi dari data-data perusahaan dan studi pustaka. Data sekunder terdiri dari kondisi perusahaan (sejarah, visi-misi, struktur organisasi) dan kondisi lingkungan (kondisi perusahaan, inventaris alat, kebersihan, dan fasilitas perusahaan).

Hasil kegiatan berupa data primer dan sekunder dengan berbagai peubah disajikan secara deskriptif. Hasil kegiatan pengujian berupa persentase hasil diolah dengan menggunakan analisis ragam dan uji nilai tengah.

\section{HASIL DAN PEMBAHASAN}

\section{Kondisi Umum}

Pusat Penelitian Kelapa Sawit Marihat terletak di Marihat, Pematang Siantar kabupaten Simalungun propinsi Sumatera utar dengan jarak $135 \mathrm{Km}$ di sebelah selatan Medan. Areal kompleks termasuk dalam konsesi PTP Nusantara IV. Pusat Penelitian Kelapa Sawit Marihat mempunyai topografi lahan dengan ketinggian 
369 meter di atas permukaan laut, curah hujan rata-rata $3331 \mathrm{~mm} /$ tahun dengan jumlah hari hujan rata-rata 184 hari dan kisaran suhu minimum $20^{\circ} \mathrm{C}$ dan maksimum $33^{\circ} \mathrm{C}$. Jenis tanah yaitu tanah Podzolik dengan $\mathrm{pH}$ rata-rata berkisar antara 5,0-6,0. Berdasarkan kelas kesesuaian lahan maka kebun PPKS Marihat termasuk ke dalam kelas S1. Kebun produksi yang dimiliki Pusat Penelitian Kelapa Sawit Marihat bekerja sama dengan PTPN IV. Luas kebun produksi benih yang dimiliki adalah 137.28 ha dengan rincian 110.27 ha untuk pohon induk betina dan 27.01 ha untuk pohon induk jantan. Lokasi kebun produksi benih Marihat terdiri dari Bah Jambi, Balimbingan, Benoa, dan Dalu-Dalu. Tahun tanam untuk tanaman yang dijadikan pohon produksi tandan benih yaitu tahun tanam 1983, 1987 dan 2000.

\section{Pemuliaan Tanaman Kelapa Sawit}

Pemuliaan tanaman kelapa sawit merupakan salah satu kegiatan paling pertama dalam memproduksi benih. Kegiatan analisis dan pemuliaan tanaman diteliti di Divisi BRD (Breeding and Research Development) yang bekerja sama dengan Kelompok Peneliti Pemuliaan. Kegiatan analisis dan pemuliaan tanaman kelapa sawit terdiri dari analisis tandan, persilangan tanaman, analisis vegetatif, dan penimbangan tandan.

Analisis tandan merupakan kegiatan pemuliaan dimana menganalisis kadar minyak dari tandan produksi. Metode yang digunakan untuk menganalisis minyak yaitu metode Sohxlet. Secara garis besar, kegiatan pengujian analisis minyak disajikan dalam Gambar 1.

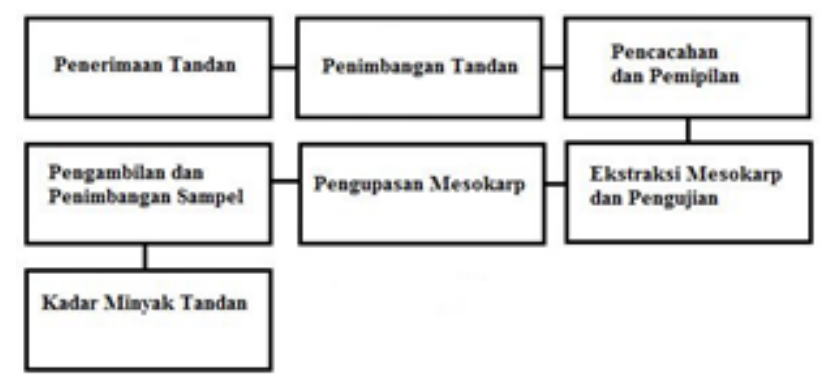

Gambar 1. Alur proses pengujian kadar minyak

Berondolan yang dijadikan sampel yaitu sebanyak 30 butir setiap tandan dengan rincian tandan bagian atas sebanyak 10 butir yang berwarna paling gelap, tandan bagian tengah dalam yang ditandai dengan warna gelap dan oranye yang seimbang sebanyak 10 butir dan bagian terdalam yang ditandai dengan warna kuning cerah sebanyak 10 butir. Secara umum kadar minyak yang terdapat pada tandan berkisar antara $20 \%-26 \%$.

Persilangan yaitu kegiatan pemuliaan yang paling utama. Kegiatan pemuliaan kelapa sawit dikenal dengan nama RRS (Resiprocal Recurrent Selection) yaitu persilangan yang berbasis karakter/sifat tanaman dari dua populasi dasar (Sulistyo, 2010). Keunggulan dalam metode ini yaitu dapat mengetahui daya gabung khusus dan daya gabung umum, namun kelemahannya terlalu sedikit jumlah individu yang dapat diuji yaitu hanya dua populasi dasar saja (Lubis, 2008). Persilangan yang dilakukan yaitu antara jenis dura sebagai tetua betina dan pisifera sebagai tetua jantan.

Analisis Vegetatif merupakan analisis pertumbuhan tanaman kelapa sawit yang terdiri dari tinggi, diameter, panjang rachis, lebar, jumlah dan panjang anak daun. Dalam analisis pemuliaan, karakter pertumbuhan tanaman kelapa sawit diharapkan lambat sehingga tumbuh pendek, hal ini dimaksudkan agar memudahkan pemanen.

Penimbangan yaitu analisis pemuliaan dimana menganalisis berat tandan produksi untuk dijadikan minyak dalam hal ini berjenis tenera.

\section{Produksi Tandan Benih}

Produksi tandan benih secara spesifik dilakukan di Divisi Pohon Induk. Divisi ini merupakan divisi yang memproduksi tandan dari hasil pemuliaan dan analisis Divisi Pemuliaan. Divisi pohon induk memiliki dua fokus utama dalam memproduksi tandan benih yaitu pohon induk dan pohon bapak. Kegiatan di pohon bapak yaitu memproduksi tandan jantan serta mengolahnya menjadi serbuk sari siap digunakan. Kegiatan di pohon induk merupakan kegiatan yang memproduksi tandan langsung di lapang. Kegiatan produksi tandan benih disajikan dalam Gambar 2.

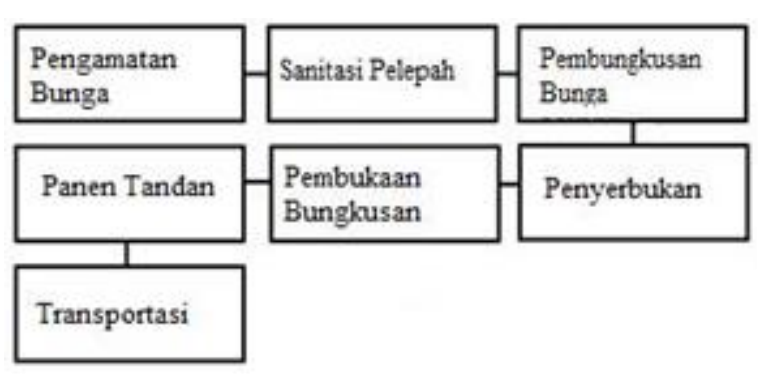

Gambar 2. Alur kegiatan produksi tandan benih

Kegiatan persilangan dan sanitasi tanaman dilakukan oleh pollinator. Kegiatan pengamatan bunga diamati setiap hari. Bunga yang siap bungkus minimal telah $25 \%$ terbuka 
seludangnya. Sebelum dibungkus, bunga yang terbungkus seludang dibuka dan dilakukan sanitasi pada areal sekitar bunga. Bunga yang siap serbuk ditandai dengan aroma yang harum dan banyak serangga berkumpul. Tandan siap dibuka pada umur 15 hari setelah diserbuki yang kemudian dapat dipanen pada umur 4,5-5 bulan dengan tingkat fraksi nol (85\%).

\section{Pengolahan Tandan Benih}

Persiapan Benih. Pengolahan tandan benih dilakukan di divisi Produksi sebagai divisi yang menjadi fokus kegiatan magang. Kegiatan pengolahan tandan dimulai dari unit persiapan benih. Pada unit ini, tandan benih hasil pemanenan dari divisi Pohon Induk diterima. Tandan yang diterima selanjutnya dicincang. Pencincangan tandan dilakukan manual menggunakan kapak secara hati-hati hanya menyisakan bagian stalknya saja. Kegiatan pencincangan dilakukan di bak khusus pencincangan, potongan spikelet hasil pencincangan kemudian dikumpulkan di keranjang penampung yang selanjutnya difermentasi selama 7 hari. Fermentasi bertujuan untuk memudahkan dalam pemipilan tandan, tandan yang baru dicincang sangat sulit untuk dipipil dikarenakan masih dalam kondisi belum matang sepenuhnya. Berondolan yang telah dipipil kemudian dikupas dengan menggunakan mesin pengupas depericarper. Lamanya waktu mengupas tergantung mesin, untuk depericarper turbo, lamanya waktu mengupas selama 10 menit sedangkan depericarper horizontal membutukan waktu mengupas selama 60-90 menit. Benih yang telah dikupas selanjutnya direndam dithane $0,1 \%$ kemudian dikering-anginkan. Benih yang telah kering kemudian dikikis sisa sabut mesokarp di bagian ujung benih. Pengikisan bertujuan untuk mengurangi potensi terjadinya jamur. Selain dikikis juga dihitung populasi benih.

Pengiriman tandan benih dari Divisi Pohon Induk dilakukan setiap hari senin dan selasa untuk tandan yang berasal dari kebun Marihat, serta hari kamis untuk tandan yang berasal dari kebun Dalu-Dalu (Riau). Banyaknya jumlah tandan yang dikirim bervariasi, tergantung musim dan kondisi tanaman, umumnya tandan yang dikirim akan lebih sedikit jumlahnya pada musim hujan, dan meningkat pada musim panas.
Tabel 1. Penerimaan tandan unit persiapan benih bulan Januari-Juni 2011

\begin{tabular}{ccc}
\hline \multirow{2}{*}{ Bulan } & \multicolumn{2}{c}{ Jumlah Tandan } \\
& Marihat/Bah Jambi & Dalu-Dalu (Riau) \\
\hline Januari & 1667 & 334 \\
Februari & 1341 & 335 \\
Maret & 1203 & 376 \\
April & 1575 & 390 \\
Mei & 1527 & 395 \\
Juni & 1324 & 362 \\
\hline
\end{tabular}

Pematahan Dormansi. Unit ini bertugas untuk mematahkan dormansi benih untuk selanjutnya dikecambahkan. Alur kegiatan pematahan dormansi dijabarkan dalam Gambar 3.

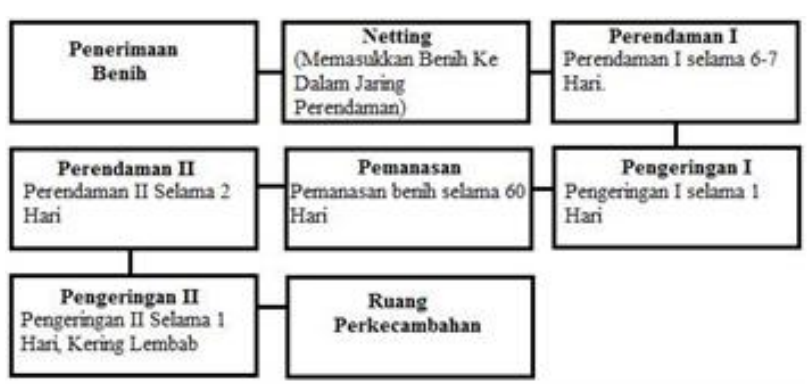

Gambar 3. Alur pematahan dormansi

Tahapan-tahapan proses pematahan dormansi yaitu: benih dari unit persiapan benih kemudian dimasukkan ke dalam net perendaman lalu direndam bagian pertama selama 6 hari. Setelah perendaman pertama, kemudian dikeringanginkan selama 1 hari. Benih yang telah kering diletakkan di dalam tray pemanas berwarna kuning, selanjutnya dimasukkan ke dalam ruang pemanas yang dilapisi lempengan besi selama 60 hari dengan suhu fluktuatif antara $38^{\circ} \mathrm{C}-40^{\circ} \mathrm{C}$. Setiap minggunya dilakukan pendinginan di suhu kamar selama 5-10 menit kemudian dimasukkan kembali ke dalam ruang pemanas. Pendinginan benih dilakukan sebanyak 8 kali yang dicatat dalam papan kontrol pemanas.

Perkecambahan. Benih yang telah selesai ruang pemanas selanjutnya dimasukkan ke net perendaman, lalu direndam kedua kalinya dengan lama waktu 2 hari. Setelah 2 hari kemudian direndam dithane lalu dikeringanginkan tetapi tidak sampai kering, hanya sampai kering lembab. Benih yang telah kering lembab selanjutnya masuk ke dalam ruang perkecambahan. Ruang perkecambahan memiliki struktur yang sama dengan ruang pemanas, hanya saja tidak dikondisikan untuk pemanas dan tanpa pelapisan lepengan logam. Suhu yang terdapat di ruang 
perkecambahan berkisar antara $28^{\circ} \mathrm{C}$ hingga $30^{\circ} \mathrm{C}$. Benih disusun di dalam tray perkecambahan berwarna biru. Benih kemudian disiram pertama kali setelah berumur 3 hari di ruang perkecambahan. Benih kemudian disiram selanjutnya sesuai kondisi tray, apabila kondisi benih dalam keadaan agak kering, maka dilakukan penyiraman. Dosis penyiraman pertama lebih banyak dibandingkan dengan penyiraman lanjutan hal ini dikarenakan penyiraman hingga umur perkecambahan 21 hari (umur benih berkecambah) hanya dilakukan satu kali, penyiraman lanjutan disesuaikan dengan kondisi benih apabila umur perkecambahan di bawah 21 hari. Penyiraman lanjutan dilakukan sehabis pemilihan kecambah. Kecambah yang telah tumbuh tidak hanya satu kali pemilihan saja tetapi hingga 6-12 kali pemilihan dengan selang waktu 4 hari, namun kondisi yang terjadi tidak setiap 4 hari tetapi beragam sesuai permintaan kecambah.

Daya berkecambah benih kelapa sawit memiliki karakteristik yang berbeda dengan benih tanaman musiman. Benih kelapa sawit tidak tumbuh secara serempak dan sangat dipengaruhi oleh kondisi ruang perkecambahan. Dalam satu tray perkecambahan terdapat $\pm 700-2000$ butir kecambah tergantung ukuran tandan. Pada saat benih memasuki tahap perkecambahan, penyiraman memerlukan volume semprot yang cukup banyak pada saat di awal, namun pada fase kecambah, volume semprot setelah pemilihan dan pengecekan tidak sebanyak sebelumnya, hal ini dikarenakan volume semprot yang tinggi akan mempercepat terbentuknya kecambah panjang.

\section{Identitas Tandan dan Benih}

Identitas tandan dan benih merupakan sesuatu yang sangat penting. Pemberian identitas tandan dibuat oleh divisi Pohon Induk sebagai divisi yang memproduksi dan menghasilkan tandan untuk dijadikan benih. Identitas tandan benih memiliki bentuk label yang dilaminating dan diberi kawat. Pemberian label dengan cara dikaitkan ke dalam sela-sela spikelet tandan.

Tabel 2. Form identitas tandan benih

\begin{tabular}{c|l}
\hline \multicolumn{1}{c|}{ Pos } & \multicolumn{1}{|c}{ NP (Nomor Penyerbukan) } \\
\hline & TB (Tanggal Bungkus \\
& TS (Tanggal Serbuk) \\
Kelompok & PI (Pohon Induk) \\
& PB (Pohon Bapak) \\
& REG (Registrasi) \\
& POL (Pollinator) \\
\hline
\end{tabular}

Pemberian identitas benih dibuat oleh Divisi Produksi sebagai divisi yang mengolah dan memproduksi benih yang berasal dari tandan. Pemberian identitas benih dilakukan pada saat pengiriman dan pengemasan kecambah kepada konsumen. Bentuk dari identitas benih tidak berbeda dengan identitas tandan. Identitas benih terdiri dari kelompok, nomor penyerbukan, nomor registrasi, jumlah kecambah, tanggal dikirim, tanggal pemanasan dan kode pemilih.

\section{Karakteristik Tandan}

Karakteristik tandan yang dijadikan benih merupakan tandan jenis Dura dengan tipe nigrescens yang dicirikan dengan warna hitamoranye apabila telah masak. Tandan benih memiliki kelas yang disimbolkan dengan huruf abjad. Kelas tandan dibagi menjadi A, B, C, D dan afkir. Kelas A ditandai dengan pembentukan buah yang baik pada spikelet minimal $80 \%$, Kelas $\mathrm{B}$ ditandai dengan pembentukan buah yang baik pada spikelet minimal $60 \%$. Kelas $\mathrm{C}$ ditandai dengan pembentukan buah yang baik pada spikelet minimal 40\%. Tandan Kelas D merupakan tandan yang paling sedikit terbentuknya buah yaitu sebesar $20 \%$. Kelas afkir merupakan kelas tandan yang tidak dapat diolah menjadi benih.

Tabel 3. Karakteristik tandan varietas Yangambi, Avros, dan Simalungun

\begin{tabular}{lllll}
\hline Varietas & Diameter & Panjang & Berat & Warna \\
\hline Yangambi & $48 \mathrm{~cm}$ & $55 \mathrm{~cm}$ & $45 \mathrm{~kg}$ & Ungu \\
Avros & $51 \mathrm{~cm}$ & $54 \mathrm{~cm}$ & $40 \mathrm{~kg}$ & Ungu-Oranye \\
Simalungun & $45 \mathrm{~cm}$ & $45 \mathrm{~cm}$ & $31 \mathrm{~kg}$ & Ungu \\
\hline
\end{tabular}

Kondisi kematangan tandan yang dipanen antara $85-90 \%$ (Fraksi nol) dan tidak boleh ada terlihat memberondol. Berat tandan yang telah dipanen bervariasi antara 30 kilogram hingga 70 $\mathrm{kg}$. Secara umum perbedaan varietas antar tandan benih tidak memiliki perbedaan yang mencolok, mayoritas berukuran dan berbentuk sama.

Stalk dan spikelet merupakan bagian yang cukup penting dalam produksi benih. Stalk merupakan bagian tempat melekatnya spikelet memiliki proporsi yang cukup besar yaitu antara 20\%-50\% berat tandan. Tiap bagian spikelet memiliki karakteristik ukuran, bentuk dan jumlah berondolan yang berbeda beda. Bagian atas tandan merupakan bagian yang meruncing, sedangkan bagian bawah tandan merupakan bagian yang terdapat potongan stalk.

Bagian atas tandan memiliki karakter 
spikelet yang berukuran sedang-kecil dengan jumlah berondolan total berkisar antara 18-26 butir dengan berondolan yang terbentuk baik sebanyak 9-12 butir (50\%). Bagian tengah tandan memiliki karakter spikelet yang berukuran sedang-besar dengan jumlah berondolan total sebanyak 28-33 butir dengan berondolan yang terbentuk baik sebesar 22-26 butir (75\%). Bagian bawah memiliki karakter spikelet yang besar dan melebar namun berukuran pendek, pada bagian ini, jumlah berondolan total antara 16-22 butir dengan jumlah berondolan terbentuk baik sebesar 11-13 butir (50\%).

\section{Karakteristik Benih}

Benih-benih yang dihasilkan oleh Pusat Penelitian Kelapa Sawit sebanyak 9 jenis, dengan 8 jenis yang telah aktif diproduksi terdiri dari Yangambi, Avros, Simalungun, Dumpy, PPKS 540, PPKS 718, Lame dan Langkat serta 1 jenis yang masih dalam tahap produksi yaitu PPKS 239.

Tabel 4. Berat mesokarp dan benih antar varietas tiap letak

\begin{tabular}{|c|c|c|c|c|c|c|}
\hline \multicolumn{4}{|c|}{ Mesokarp (gr/90 butir) } & \multicolumn{3}{|c|}{ Benih (gr/90 butir) } \\
\hline \multirow{2}{*}{$\mathrm{ak}$} & & VAR & VAR & VAR & VAR & VAR \\
\hline & & A & $\mathrm{S}$ & $\mathrm{Y}$ & A & $\mathrm{S}$ \\
\hline L1 & 470 & 700 & 540 & 450 & 200 & 285 \\
\hline L2 & & & 575 & 350 & 250 & 50 \\
\hline L3 & & & 500 & 360 & 220 & 50 \\
\hline L4 & & & 750 & 45 & 30 & \\
\hline L5 & & & 660 & 450 & 250 & 50 \\
\hline L6 & 42 & 440 & 590 & 38 & 31 & 510 \\
\hline L7 & & & $J$ & 400 & 270 & 80 \\
\hline L8 & & 550 &  & 41 & 250 & 10 \\
\hline L9 & & & $5 / 5$ & 380 & 225 & 285 \\
\hline Rata- & 5090 & 5195 & 5385 & 3630 & 2275 & 2920 \\
\hline rat & $(58 \%)$ & $(69 \%)$ & $(64 \%)$ & $(42 \%)$ & $(31 \%)$ & $(36 \%$ \\
\hline
\end{tabular}

Setelah hasil penimbangan sampel berondolan dan benih dari ketiga varietas didapat yaitu mesokarp pada benih memiliki proporsi berat total antara 58\%-69\% dengan rerata 63\% sedangkan benih memiliki proporsi berat total antara 31\%-42\% dengan rerata $36,11 \%$. Bedasarkan hasil, benih dan berondolan yang memiliki bobot total terberat berada pada bagian tengah baik pada ketiga varietas.

Varietas-varietas yang menjadi fokus pengujian terdiri dari tiga varietas yaitu varietas Yangambi, Avros dan Simalungun dengan tipe Dura. Benih varietas Yangambi memiliki karakteristik berukuran sedang-besar, dengan tingkat kemunculan benih poliembrio yang besar, varietas ini umumnya mulai berkecambah pada umur perkecambahan 20-21 hari perkecambahan. Benih varietas Avros merupakan benih berukuran kecil-sedang, dengan tingkat kemunculan benih non inti yang cukup besar, varietas ini umumnya berkecambah pada umur 25-27 hari perkecambahan. Benih varietas Simalungun merupakan benih yang berukuran paling besar beserta intinya, varietas ini umumnya berkecambah pada umur 20-21 hari perkecambahan. Kecambah yang dipilih ditandai dengan panjang plumula dan radikula total maksimal $2 \mathrm{~cm}$, hal ini didasari apabila benih dikemas di dalam plastik, pada saat perjalanan tidak patah plumula dan radikulanya.

\section{Analisis Hasil Pengujian Tetrazolium dan Daya Kecambah}

Faktor-faktor pengujian yang diduga memiliki pengaruh terhadap produksi kecambah yaitu faktor letak berondolan dan varietas tandan. Pemilihan faktor-faktor yang dianalisis didasarkan pada asumsi penulis terhadap keragaman ukuran dan bentuk berondolan yang berbeda-beda tiap posisi berondolan di tiap bagian tandan. Peubahpeubah yang diamati dalam analisis ini terdiri dari persentase viabilitas tetrazolium, persentase benih non inti, persentase daya kecambah, potensi tumbuh maksimum dan persentase kecambah abnormal.

\section{Rekapitulasi Analisis Ragam}

Berdasarkan tabel 5, hasil pengujian didapatkan bahwa peubah-peubah yang mempengaruhi hasil pengujian terdiri dari viabilitas tetrazolium, daya kecambah dan potensi tumbuh maksimum. Peubah yang memilik pengaruh terkuat yaitu viabilitas tetrazolium. Pengaruh Daya Kecambah dan Potensi Tumbuh Maksimum memberikan pengaruh yang nyata pada hasil.

Tabel 5. Rekapitulasi analisis ragam

\begin{tabular}{llll}
\hline Peubah & Varietas & Letak & $\mathrm{V} * \mathrm{~L}$ \\
\hline Viabilitas Tetrazolium & $* *$ & $* *$ & $* *$ \\
Daya Kecambah & $* *$ & $* *$ & $*$ \\
$\begin{array}{l}\text { Potensi Tumbuh } \\
\text { Maksimum }\end{array}$ & $* *$ & $* *$ & $*$ \\
\hline
\end{tabular}




\section{Viabilitas Tetrazolium Embrio}

Hasil pengujian viabilitas tetrazolium embrio benih kelapa sawit untuk setiap bagian pada ketiga varietas yang diuji memiliki hasil yang berbeda-beda. Letak benih yang menjadi pengamatan terbagi menjadi 9 bagian yaitu L1 (1/3 atas), L2 (1/5 atas), L3 (1/10 atas), L4 (1/3 tengah), L5 (3/5 tengah), L6 (4/5 tengah), L7 (1/3 bawah), L8 (1/5 bawah) dan L9 (1/10 bawah). Tingkat presentase viabilitas tetrazolium disajikan dalam Gambar 4.

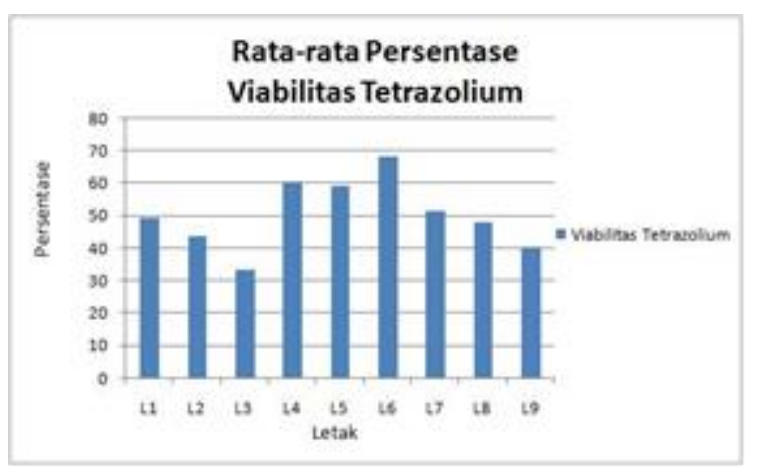

$\begin{array}{ccr}\text { Gambar 4. } & \text { Rata-rata Persentase } & \text { Viabilitas } \\ & \text { Tetrazolium Tiga } & \text { Varietas } \\ & \text { Terhadap Letak Benih } & \end{array}$

Benih yang berada pada bagian tengah memiliki nilai presentase viabilitas yang paling tinggi. Bagian tengah tandan diwakili oleh letak L4 sebesar $60 \%$, L5 sebesar 58,89\%, dan L6 sebesar $67,78 \%$. Secara umum letak benih antara L1 (48,89\%), L7 (51,11\%) dan L8 (47,78\%) tidak memiliki hasil yang jauh berbeda. Letak benih yang memiliki daya kecambah paling kecil yaitu pada L3 sebesar $33.33 \%$. Hasil pada letak tandan bagian bawah yaitu L7 (51,11\%), L8 (47,78\%) dan L9 (40\%) memiliki hasil yang lebih baik dari letak tandan bagian atas yaitu L1 $(48,89 \%)$, L2 $(43,33 \%)$ dan L3 (33.33\%).

\section{Daya Berkecambah}

Hasil pengamatan pengujian memiliki pola seperti pada uji viabilitas tetrazolium. Pengujian daya kecambah dilakukan selama 35 hari. Benih-benih yang masuk dalam kategori daya kecambah yang baik yaitu benih yang pertumbuhan plumula dan radikula maksimal 2 $\mathrm{cm}$ dan tidak mengalami pertumbuhan abnormal. Hasil menunjukkan bahwa berdasarkan letak benih-benih di dalam tandan, bagian tengah yang diwakili oleh letak L4, L5, dan L6 memiliki nilai presentase daya kecambah yang lebih tinggi dibandingkan dengan bagian atas ( L1, L2 dan L3)dan bagian bawah (L7, L8, L9). Presentase daya kecambah tiga varietas kelapa sawit disajikan dalam Gambar 5.

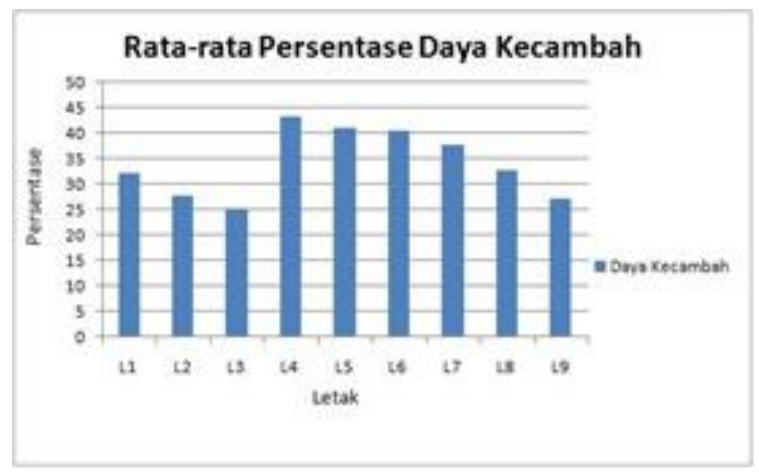

Gambar 5. Rata-rata Persentase Daya Kecambah Tiga Varietas Terhadap Letak Benih

Bagian tengah tandan diwakili oleh letak L4 sebesar $43.33 \%$, L5 sebesar $41,11 \%$ dan L6 sebesar $40.55 \%$. Hasil pada letak tandan bagian bawah yaitu L7 (37.77\%), L8 (32.77\%) dan L9 (27.22\%) memiliki hasil yang lebih baik dari letak tandan bagian atas yaitu L1 (32.22\%), L2 (27.78\%) dan L3 (25\%). Letak benih yang memiliki daya kecambah paling kecil yaitu pada L3 sebesar 25\% dan letak benih yang memiliki daya kecambah terbesar terletak pada L4 sebesar $43.33 \%$.

\section{KESIMPULAN}

Untuk menghasilkan kecambah yang baik tahapan pertama yang dilakukan yaitu pemuliaan yang dilakukan di Divisi Pemuliaan, kegiatan pemuliaan yang dilakukan yaitu menganalisis persilangan tanaman untuk dijadikan tetua produksi. Tahapan kedua yaitu produksi tandan yang dilakukan di Divisi Pohon Induk. Kegiatan produksi tandan terdiri dari produksi tandan jantan kemudian diolah menjadi tepung sari siap serbuk, dan kegiatan persilangan bunga jantan untuk membentuk tandan benih. Tandan yang telah dipanen selanjutnya dikirim ke bagian pengolahan tandan menjadi benih yaitu Divisi Produksi.

Pengolahan tandan menjadi benih di Divisi Produksi terdiri dari 3 tahap yaitu persiapan benih, pematahan dormansi dan perkecambahan. Persiapan benih merupakan kegiatan mengolah tandan benih menjadi benih utuh. Tahapan persiapan benih yaitu pencincangan, fermentasi, pengupasan, dan pengikisan. Pematahan dormansi merupakan kegiatan untuk mematahkan sifat dormansi yang terdapat pada benih, tahapan kegiatan pematahan dormansi terdiri dari, perendaman yang dilakukan dua tahap, pemanasan dan pengeringan. Perkecambahan merupakan kegiatan mengecambahkan benih 
menjadi kecambah siap tanam, tahapan kegiatan perkecambahan yaitu pelembaban, penyiraman, dan pemilihan.

\section{DAFTAR PUSTAKA}

Lubis, A.U. 2008. Kelapa Sawit (Elaeis guineensis Jacq) di Indonesia Edisi kedua. Pusat Penelitian Perkebunan Marihat. Sumatera Selatan. 435 hal.

Pahan, I. 2010 .Paduan Lengkap Kelapa Sawit Manajemen Agribisnis dari Hulu hingga Hilir (Cetakan ke VII). Jakarta (ID): Penebar Swadaya.
Pranoto, H.S., W.Q. Mugnisjah, E. Muniarti. 1990. Biologi Benih. Pusat Antar Universitas Ilmu Hayati Institut Pertanian Bogor. Bogor. 137 hal.

Sadjad, S., H. Suseno, S.S. Harjadi, J. Sutakaria, Sugiharso, Sudarsono. 1980. Dasar-Dasar Teknologi Benih Kapita Selekta. Dep. Agr. IPB. Bogor. 216 hal.

Sulistyo, B. 2010. Budidaya Kelapa Sawit. Balai Pustaka. Jakarta. 190 hal. 